\title{
GLOBALIZATION AND INDUSTRIAL DEVELOPMENT IN NIGERIA: A CURSE OR CURE?
}

\author{
Olufemi Samuel Omoyele ${ }^{1}$, Ojo, B. Lucas ${ }^{2}$, Wahid Damilola Olanipekun ${ }^{3}$, Timothy \\ Ayomitunde Aderemi ${ }^{4 *}$ \\ ${ }^{1}$ Department of Business Administration and Marketing, Redeemer's University, Ede, Osun \\ State, Nigeria \\ ${ }^{2}$ School of Technical Education, Yaba College of Technology, in Affiliation with University \\ of Nigeria, UNN, Usukka, Nigeria \\ ${ }^{3}$ College of Management and Information Technology, American International University \\ West Africa, Gambia \\ ${ }^{4}$ Department of Economics, Accounting and Finance, Bells University of Technology, Ota, \\ Nigeria \\ olufemi5n@gmail.com \\ lucasojobab@yahoo.com \\ W.olanipekun@aiu.edu.gm \\ taaderemi@bellsuniversity.edu.ng
}

\begin{abstract}
The question whether globalization and its corresponding impacts carry a blessing or curse in developing countries has been a controversial issue among both the scholars and the policymakers, against this background this study provided an empirical answer to the question whether globalisation is a curse or cure to industrial development in Nigeria between 1990 and 2019 within the framework of the Fully Modified Ordinary Least Squares (FMOLS) and Granger causality test. Consequently, the following principal findings emerged in this study. Firstly, both FDI inflows and trade openness which depict economic globalization had a negative relationship with industrial development respectively. Though, trade openness was significant while FDI inflows showed otherwise. In the same vein, a unidirectional causality ran from manufacturing value added to FDI inflows. However, no feedback relationship existed between trade openness and manufacturing value added. Therefore, this study submits that economic globalization is a curse to industrial development in Nigeria because the wave of economic globalization contributed a significant reduction in manufacturing value added in Nigeria in the last three decades. From these findings, the current wave of economic globalization could be a cure to industrial development in Nigeria, if only the policymakers in the country embark on policies that would drive the largest proportion of the inflows of FDI in the direction of manufacturing sub sector in the country. Similarly, all hands must be on deck by all the relevant stakeholders to ensure that manufactured products in Nigeria possesses value added quality to facilitate their competitiveness in the global market.
\end{abstract}

Keywords: Globalization, Industrial Development, Trade Openness, FDI, Curse, Cure.

JEL Classification: F43; F62.

\section{Introduction}

\footnotetext{
* Corresponding author: Timothy Ayomitunde Aderemi Cite as:

Omoyele, O.S., Lucas, B.O,m Olanipekun, W.D. and Aderemi, T.A., 2021. .

Oradea Journal of Business and Economics, 6(2), pp. 88-97.

http://doi.org/10.47535/1991ojbe132
} 
The wave of globalization has been continuously intensifying in shaking all the spheres of the global economy in the past few decades (Aderemi et al., 2020; Kovárová, 2017; Kaya, 2010; Baldwin \& Forslid, 2000). Because the integration of the global market in the $21^{\text {st }}$ century has been an unprecedented phenomenon owing to the advent of digital technologies, rising trade liberalization and international financial flows.

However, industrialization is considered to be one of the strategic components in achieving long-term and sustainable development, in the case of developing economies its impact on employment creation and reduction of poverty cannot be undermined. Evidence has shown that the industrial revolution that characterized the Western Europe and the United States in the 19th and early 20th centuries has always been the reference point for scholars and policy analysts in advocating for industrial development as developmental framework in developing countries. In the recent times, the sporadic expansion of aggregate outputs in some emerging countries such as China, India and other 'Asian Tigers' show that industrialization is a paramount condition for economic prosperity. Meanwhile, patterns of the Nigeria`s trade show that the country's commodities lack value addition, commodity diversification, dominant proportion of primary goods and over reliance on developed countries for valued added products (World Bank, 2016). This is a clear indication that industrial development is operating at low ebb in Nigeria.

Succinctly put, industrial development in Nigeria has been a major concern for scholars in one hand, whereas multiplier effects of external factors on the development of manufacturing sector in Nigeria has long remained a subject of debate in the literature on the other hand. Due to the various events that have unfolded in the global market, the earlier writers have conceptualized globalization as unavoidable curse and fortune to developing countries (Rodrik, 1999; David, 1999; Salimono, 1999; Awake, 2002; Garry, 1998; Gondwe, 2001; Dollar, 2001). But further efforts to unravel the linkage between globalization and industrial development in Nigeria has largely received little or no attention in the literature, especially in the most recent times. The focus of the larger bulk of recent studies in Nigeria was the nexus between globalization and economic growth (Imandojemu et al., 2021; Letswa et al., 2018; Okpokpo, Ifelunini and Osuyali, 2014; Akor, Yongu, and Akorga, 2012). However, few studies such as Ebong, Udoh and Obafemi (2014), Toyin (2017) and Binuyo et al. (2017) which examined impact of globalization on industrial development in Nigeria were observed to be deficient in terms of measurement of industrial development variable and technique of analysis. In order to improve the existing studies in the country, this current study employed manufacturing value added in measuring industrial development, in which to the best of knowledge, no study has utilized in Nigeria. In view of the above, this examined impact of globalization on industrial development from 1990 to 2019, using Nigeria data. As a departure from the existing studies, it is instructive to stress that the novelty of this study lies in the fact it both employed a better measurement of industrial development and most updated recent data in which no study has incorporated in the literature.

The rest of this work is structured as follows; having provided the background information and established the problem of the study in the introduction, section two presents the adequate and updated review of past studies. Also, section three contains methodology, discussion of results, summary and policy implication of the study.

\section{Literature Review}

The ongoing rise in interdependence among the global economies alongside people migration which arises as results of digital technology, flows of investment, cross-border trade in goods and services, and the integration of markets, trade and investments with few barriers to slow the flow of products and services between nation have made globalization one of the most popular issues of concerns, especially how it affects industrial development which refers to social organization in which industries and especially large-scale industries 
are dominant, among both the scholars and policymakers in the $21^{\text {st }}$ century. Globally, public policy changes and communications technology innovations have sped up globalization to an unprecedented pace, free market economic system through fiscal policies and trade agreements, removal or reduction of tariffs have been integrated by government over the last 2 decades. However, recent studies by (Onwuka \& Eguavoen, 2018; Uwadiegwu, 2015) show that the driving force of globalization process are technology, policy and competition, this exposes the domestic economies to the forces of the global market. Meanwhile, the authors argued that globalization had not benefited Nigeria owing to monocultural export, huge debt profile and inability of the country to attract substantial foreign investments. This implies that reduction in debt profile and diversification of export base in conjunction with a rise in development cooperation with other economies will aid industrial development in a developing nation like Nigeria. Similarly, unequal effect of globalization has preponderantly distorted third world economic growth and development, therefore to eliminate the negative effect of globalization which is vehicle for economic development of Nigeria and other 3rd world countries, there is the urgent need to explore the positive side of globalization which is in tandem with global best practices in economic recovery (Dappa \& Thom-otuya, 2010). In a research conducted by (Odo, Agbo, \& Agbaji, 2020), the study discovered that whereas globalization may have improved the economies of advanced democracies, the domestic economy received marginal benefits, this marginal benefit enjoyed by developing economies is undermined by weak technical base, unhealthy macro-economic environment and poorly diversified economic base. This suffice to asserts that to attain even industrial development in a developing nation like Nigeria, there is a need for strong, healthy macro-economic and diversified economic base. Also, it is amazing that, the moderate performance of the capital market has not actually translated into a remarkable growth of the industrial sector in Nigeria. Akindele, Jogunola, and Aderemi (2019) applied DOLS and Granger causality techniques to explore the linkage between globalisation and real estate development in Nigeria between 1990 and 2016. The authors posited that globalisation exerted a positive and significant impact on real estate development in the country. Also, FDI Granger caused real estate development in the country. A Cointegration Approach was employed by (Agbarha \& Peter, $2017)$ to explore the relationship between major globalization indicators and economic growth in Nigeria, the result showed that current FDI and one period lagged FDI, one period lagged exchange rate, current balance of payment and two period lagged openness of the economy to the outside world have a positive and significant impact on the level of economic growth in Nigeria. Industrialization is said to be a hallmark for modern economic growth and development but the Nigerian industrial sector has suffered from decades of low productivity and currently in state of coma. In the same vein similar study reveals that foreign direct investment had an inverse relationship with economic growth in Nigeria (Imandojemu, 2021). Similarly, cointegration tests and the Short and Long Run Dynamics Autoregressive Distributed Lag (ARDL) test was employed by (George-Anokwuru, 2018) it was discovered that import is negatively related to Gross Domestic Product and significant effects on industrial growth, whereas export increased growth of the Nigerian economy. Other recent studies on the effects of globalization on economic growth in Nigeria reveals that over dependence on crude oil exports, low export of locally produced goods among others are the impediments to the even globalization experience in Nigeria (Okpokpo, Ifelunini, \& Osuyali, 2014; Feridun, Olusi, \& Folorunso, 2006).

Furthermore (Adofu \& Okwanya, 2017; Uwadiegwu, 2015; Binuyo, Oluwadare, Adeoye, Olanrewaju, \& Obiakor, 2017) have tried to examines the effect of trade openness and total factor productivity on industrial output in Nigeria, while using Vector Autoregressive (VAR) analysis to measure the effect of trade openness and total factor productivity on industrial output in Nigeria, the outcome of the study shows that that trade openness has a positive increasing effect on industrial output in Nigeria while the effect of total factor productivity on industrial output is found to be insignificant. There is the need to avert globalization of 
poverty in Nigeria as the foregoing studies posit that Nigeria is in the verge of complete collapse of her industrial sector if the Nigerian government do not rise to safe her from the precipice of collapse by aiding the industrial sector in terms of tax holidays, tax relief, exemptions among others.

\section{Methodology}

The relationship between globalization and industrial development in Nigeria has been examined in this study. Achieving this objective required that an ex-post facto research design is considered appropriate because the study explores the viable relationship, and as well describes how globalization predicts variation in industrial development in Nigeria. Consequently, the study used annual data which was extracted from the World Development Indicators. The scope of the study was between 1990 and 2019. 1990 was exclusively chosen as the base year because the adoption of the popular SAP in Nigeria in 1987 sparked off the sporadic inflows of foreign capital into the economy from the early 1990s.

\section{Model Specification}

In building empirical model for this study, two of the relevant "KOF Globalization Index" enunciated by Dreher, Gaston and Martens (2008) serves as a guide for this study. However, "KOF Globalization Index" categorizes globalization into three phenomena namely economic, political and social. Whereas, the economic dimension of globalization, which is the central focus of this paper emphasizes international capital flows via FDI and trade openness. Therefore, in adapting for this study, an insight was drawn from the works of and Parisa and Hashem (2014), Aderemi et al. (2020), and Olowookere et al. (2021) by eliminating variables that do have any link with this study. The functional form of the model is illustrated as follows;

Industrial Development $=f$ (Globalisation)

$$
\text { IDM }=f(F D I, T R O)
$$

Introducing some control variables to model (1), the classic Cobb-Douglas production function of the model could be enunciated as

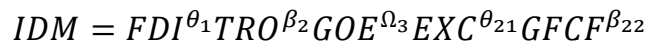

Introduction of the natural logarithm to model (2) in order to satisfy the conventional linearity assumption of the OLS transform the model to a linear equation as follows;

$\operatorname{LogIDM}_{t}=a+\theta_{1} \operatorname{LogFDI}_{t}+\beta_{2} \operatorname{LogTRO}_{t}+\Omega_{3} G O E_{t}+\theta_{11} \operatorname{LogEXC}_{t}+\beta_{22} \operatorname{LogGFCF}_{t}+\mu_{t}$

\section{Where:}

IDM is used to denote industrial development. This is measured by manufacturing value added as percentage of GDP, which its unit is in percentage. FDI is proxied by FDI inflows which is in million dollars. TRO is trade openness measured as addition of imports and exports as percentage of GDP. Its unit is in percentage. GOE is total government expenditures in billion dollars. EXC is exchange rate, which measures the value of the country`s currency vis-à-vis dollar. GFCF is gross fixed capital formation as percentage of GDP. $u$ is error term. $t$ represents the period of the analysis. Meanwhile, it is expected that the parameters have positive sign. 


\section{Results and Discussion}

Table 1: Descriptive Statistics of Annual Data Series (1990 -2019)

\begin{tabular}{|l|l|l|l|l|l|l|}
\hline $\begin{array}{l}\text { Descriptive } \\
\text { statistics }\end{array}$ & IDM & EXC & FDI & GOE EXP & GFCF & TRO \\
\hline Mean & 12.67290 & 121.6748 & 1.730667 & 4.300933 & 28.43333 & 35.94583 \\
\hline Median & 11.19200 & 127.2300 & 1.575000 & 4.474000 & 26.05000 & 37.62500 \\
\hline Maximum & 20.92700 & 306.9210 & 5.790000 & 9.448000 & 53.10000 & 53.28000 \\
\hline Minimum & 6.553000 & 8.038000 & 0.500000 & 0.911000 & 14.10000 & -5.935000 \\
\hline Std. Dev. & 4.660987 & 88.82786 & 1.177985 & 3.011154 & 12.21913 & 11.62859 \\
\hline Skewness & 0.439744 & 0.587829 & 1.942353 & 0.373899 & 0.474313 & -1.465005 \\
\hline Kurtosis & 1.640073 & 2.781034 & 7.020928 & 1.685217 & 1.985835 & 6.768675 \\
\hline Jargue- Bera & 3.278627 & 1.787649 & 39.07350 & 2.859820 & 2.410525 & 28.48483 \\
\hline Probability & 0.194113 & 0.409088 & 0.000000 & 0.239330 & 0.299613 & 0.000001 \\
\hline Sum Sq. & 380.1870 & 3650.245 & 51.92000 & 129.0280 & 853.0000 & 1078.375 \\
\hline $\begin{array}{l}\text { SUM. Sq. } \\
\text { dev }\end{array}$ & 630.0192 & 228821.3 & 40.24179 & 262.9443 & 4329.907 & 3921.498 \\
\hline Observation & 30 & 30 & 30 & 30 & 30 & 30 \\
\hline
\end{tabular}

Source: Authors' calculation (2021)

One of the crucial conditions necessary for the application of econometric technique is the normal distribution of series in a given study. In view of the above, the estimated results of descriptive statistics of the various relevant variables have been reported in Table 1. Firstly, MVP which is manufacturing value added as percentage of GDP from 1990 to 2019 had $6.553 \%$ and $20.927 \%$ as minimum and maximum values respectively. The mean value of this variable is $12.67 \%$ while the standard deviation is $4.66 \%$. This shows that the variable is moderately dispersed from its mean because it has a standard deviation which is lower than the mean value. Similarly, other variables such as EXR, FDI, GEP, GFCF and TO shared identical behavior with the MVP. This implies that all the series were moderately dispersed from the mean. Meanwhile, with the exception of TO, all other series were positively skewed.

Table 2: Unit Root Test

\begin{tabular}{|c|c|c|c|c|c|c|c|}
\hline \multirow[t]{2}{*}{ Variables } & \multicolumn{7}{|c|}{ ADF TEST } \\
\hline & Level & Prob. & $1^{\text {st }}$ Dif. & Prob. & $2^{\text {nd }}$ Dif. & Prob. & Decision \\
\hline IDM & -2.967767 & 0.7008 & -2.976263 & 0.1785 & -2.976263 & 0.0000 & $\mathrm{I}(2)$ \\
\hline EXC & -2.967767 & 0.9883 & -2.971853 & 0.0072 & & & I (1) \\
\hline FDI & -2.967767 & 0.0338 & & & & & $\mathrm{I}(0)$ \\
\hline GOE & -2.967767 & 0.6390 & -2.971853 & 0.0004 & & & $\mathrm{I}(1)$ \\
\hline GFCF & -2.967767 & 0.2334 & -2.971853 & 0.0002 & & & $\mathrm{I}(1)$ \\
\hline TRO & -2.967767 & 0.3654 & -2.976263 & 0.0008 & & & I (1) \\
\hline \multirow[t]{2}{*}{ VARIABLES } & \multicolumn{7}{|c|}{ PP TEST } \\
\hline & Level & Prob. & $1^{\text {st }}$ Dif. & Prob. & $2^{\text {nd }}$ Dif. & Prob. & Decision \\
\hline IDM & $\begin{array}{l}-2.967767 \\
- \\
2.967767-2.967767\end{array}$ & 0.6812 & -2.971853 & 0.0009 & & & $\mathrm{I}(1)$ \\
\hline EXC & -2.967767 & 0.9867 & -2.971853 & 0.0105 & & & $I(1)$ \\
\hline FDI & -2.967767 & 0.0281 & & & & & $\mathrm{I}(0)$ \\
\hline GOE & -2.967767 & 0.5790 & -2.971853 & 0.0004 & & & I (1) \\
\hline GFCF & -2.967767 & 0.2132 & -2.971853 & 0.0002 & & & $I(1)$ \\
\hline TRO & -2.967767 & 0.4122 & -2.971853 & 0.0002 & & & $I(1)$ \\
\hline
\end{tabular}

Source: Authors' calculation (2021) \%5 level 
The essence of estimating a unit root test is linked with the need to verify stationarity status of the various employed data at different forms. And as such, risk of running into nonsense or spurious results in a study is mitigated through this test. Therefore, the Augmented Dickey Fuller (ADF) and Phillip Peron test (PP) were simultaneously utilized to test whether the data possesses a unit root or not. Table 2 shows the estimated results as follows; FDI inflows is stationary at level which means it is I (0) data. But EXC, GOE, GFCF and TRO are stationary after first differencing which means they are I (1) data. And IDM becomes stationary after second differencing which means it is I (2) data. Therefore, the utilized data possesses different orders of integration, this could spur a sort of divergence among the variables of interest in the short run. However, this divergence has the possibility of returning to equilibrium in the long. Hence, the Johannsen cointegration test is required in this regard to establish the existence or otherwise of long run convergence of the variables of the interest.

Table 3: Johansen Co-integration Test (Trace Statistics) and (Maximum Eigen value)

\begin{tabular}{|l|l|l|l|l|l|}
\hline $\begin{array}{l}\text { Hypothesized } \\
\text { No. of CE(s) }\end{array}$ & Eigen value & $\begin{array}{l}\text { Trace } \\
\text { Statistics }\end{array}$ & P- Value & $\begin{array}{l}\text { Max- Eigen } \\
\text { Statistics }\end{array}$ & P-Value \\
\hline None $^{*}$ & 0.873877 & 129.7924 & 0.0000 & 57.97383 & 0.0002 \\
\hline At most 1 & 0.693708 & 71.81852 & 0.0343 & 33.13003 & 0.0612 \\
\hline At most 2 & 0.479162 & 38.68849 & 0.2729 & 18.26486 & 0.4732 \\
\hline At most 3 & 0.411169 & 20.42363 & 0.3946 & 14.82926 & 0.3010 \\
\hline At most 4 & 0.179426 & 5.594371 & 0.7428 & 5.537037 & 0.6730 \\
\hline At most 5 & 0.002046 & 0.057334 & 0.8107 & 0.057334 & 0.8107 \\
\hline
\end{tabular}

Source: Authors' calculation (2021)

While establishing the existence or otherwise of long run convergence of the variables of the interest in this work, Table 3 above shows the estimated results of the long run equilibrium relationship between globalization and industrial development in Nigeria within the context of Johansen Cointegration Test. It was revealed from the above findings that there was presence of at most three (5) cointegration vectors in the estimated model. This confirms that globalization and industrial development have a long run convergence in Nigeria.

Table 4: Fully Modified Ordinary Least Square (FMOLS)

\begin{tabular}{|l|l|l|l|}
\hline Regresors & Coefficient & T- statistics & Prob. Value \\
\hline LogEXC & -0.022611 & 2.675825 & 0.0135 \\
\hline LogGFCF & 0.151141 & 2.017584 & 0.0554 \\
\hline LogGOE & -0.595712 & 3.006023 & 0.0063 \\
\hline LogTRO & -0.118355 & 3.150376 & 0.0045 \\
\hline LogFDI & -0.128702 & 0.407115 & 0.6877 \\
\hline R- Squared & 0.91 & & \\
\hline
\end{tabular}

Dependent Variable: LogIDM

Method: Fully Modified OLS

Source: Authors calculation (2021)

Table 4 shows the estimates of the long run relationship between various variables of globalization and industrial development in Nigeria using the technique of the Fully Modified Ordinary Least Squares. It could be deduced from the table that it was only LogGFCF that had the expected sign, while all other variables showed otherwise. Meanwhile, the Rsquared is 0.91 , which implies that EXC, GFCF, GOE, TRO and FDI jointly accounted for about $91 \%$ of the systematic variations in IDM. The implication of this is that the model is relatively good for this empirical analysis. Furthermore, exchange rate had a significant negative relationship with industrial development. A unit change in exchange rate would 
induce a reduction in manufacturing value added by 0.02 unit in the country. Similarly, government expenditure had an inverse but significant relationship with industrial development. A unit change in expenditure by the government induces a reduction in manufacturing value added 0.5 unit. Conversely, gross fixed capital formation and industrial development had a significant direct relationship. This implies that a unit change in this variable induces a rise in manufacturing value added by 0.15 unit. Furthermore, the economic globalization depicted by both FDI inflows and trade openness had a negative relationship with industrial development respectively. Though, trade openness was significant while FDI inflows showed otherwise. Therefore, a unit change in trade openness induces a reduction in manufacturing value added in Nigeria.

By and large, it could be submitted in this study that globalization leads to the dwindling of industrial development in Nigeria. The reasons for this result, firstly might be as a result of the largest proportion of the inflows of FDI in the direction of oil and gas sector in the past decades in the country. In the same vein, manufactured products in Nigeria might lack value added quality which could render them uncompetitive in global market. It therefore imperative to state that economic globalization is a curse to industrial development in Nigeria, because the latest wave of economic globalization contributed to a significant reduction in manufacturing value added in the country. The finding in this study validates the propositions of earlier authors such Awake (2002), Garry (1998), Gondwe (2001), Dembele (1998), Saibu and Akinbobola (2014) who held the views that globalization is curse to developing countries. Also, some other studies such as Onwuka \& Eguavoen (2018) Uwadiegwu (2015) are in tandem with the submission of this study.

Table 5: Pairwise Granger Causality Test

\begin{tabular}{|l|l|l|l|l|}
\hline Null Hypothesis & $\begin{array}{l}\text { F- } \\
\text { Statistics }\end{array}$ & Prob. & Decision & Causality \\
\hline ER does not Granger Cause IDM & 2.16759 & 0.1373 & Accept & None \\
\hline IDM does not Granger Cause ER & 0.22259 & 0.8021 & Accept & \\
\hline FDI does not Granger Cause IDM & 0.22952 & 0.7967 & Accept & \\
\hline IDM does not Granger Cause FDI & 3.57748 & 0.0444 & Reject & unidirectional \\
\hline GFCF does not Granger Cause IDM & 0.53666 & 0.5918 & Accept & \\
\hline IDM does not Granger Cause GFCF & 4.84596 & 0.0175 & Reject & Unidirectional \\
\hline GOE does not Granger Cause IDM & 0.18520 & 0.8322 & Accept & \\
\hline IDM does not Granger Cause GOE & 3.07650 & 0.0655 & Accept & \\
\hline $\begin{array}{l}\text { GFCF does not Granger Cause } \\
\text { ECR }\end{array}$ & 6.01243 & 0.0079 & Reject & Unidirectional \\
\hline $\begin{array}{l}\text { ECR does not Granger Cause } \\
\text { GFCF }\end{array}$ & 0.40169 & 0.6738 & Accept & \\
\hline TRO does not Granger Cause ECR & 1.01254 & 0.3789 & Accept & \\
\hline ECR does not Granger Cause TRO & 4.48358 & 0.0227 & Reject & Unidirectional \\
\hline $\begin{array}{l}\text { TRO does not Granger Cause } \\
\text { GFCF }\end{array}$ & 1.08027 & 0.3561 & Accept & \\
\hline $\begin{array}{l}\text { GFCF does not Granger Cause } \\
\text { TRO }\end{array}$ & 4.50772 & 0.0223 & Reject & Unidirectional \\
\hline
\end{tabular}

Source: Authors calculation (2021)

Despite the fact that a co-integrating relationship has been established between globalization and industrial development in this study, the authors made further efforts to analyze the feedback effect of various variables of interest utilizing Pairwise Granger Causality technique. Table 5 shows that a unidirectional causality flows from manufacturing 
value added to FDI inflows. However, no feedback relationship exists between trade openness and manufacturing value added. This implies that industrial development in Nigeria is a necessary condition before globalization could partly contribute fortunes to the country.

Moreover, a unidirectional causality flows from industrial development to gross fixed capital formation. Whereas, gross fixed capital formation Granger causes exchange rate, and a unidirectional feedback flow from exchange rate to trade openness. Finally, gross fixed capital formation Granger causes trade openness. This implies that the long run convergence among the variables of interest earlier established in Table 3 is validated by the estimated results of Granger causality.

\section{Conclusion and Policy Recommendation}

The question whether globalisation is curse or cure to industrial development between 1990 and 2019 has been investigated within the framework of Fully Modified Ordinary Least Squares (FMOLS) and Granger causality test. In the light of the above, the following principal findings has been emerged in this study. Firstly, exchange rate had a significant negative relationship with industrial development. Government expenditure had an inverse but significant relationship with industrial development. But, gross fixed capital formation and industrial development had a significant direct relationship. Also, both FDI inflows and trade openness had a negative relationship with industrial development respectively. Though, trade openness was significant while FDI inflows showed otherwise. Therefore, economic globalization a curse to industrial development in Nigeria because the latest wave of economic globalization contributed to a significant reduction in manufacturing value added. In the same vein, a unidirectional causality ran from manufacturing value added to FDI inflows. However, no feedback relationship existed between trade openness and manufacturing value added. This implies that industrial development in Nigeria is a necessary condition before globalization could partly contribute to fortunes to the country. Moreover, a unidirectional causality ran from industrial development to gross fixed capital formation. Whereas, gross fixed capital formation Granger caused exchange rate, and a unidirectional feedback ran from exchange rate to trade openness. Finally, gross fixed capital formation Granger caused trade openness. Therefore, from these findings, this study recommends that before the current wave of economic globalization could be a cure to industrial development in Nigeria, the policymakers in the country should embark on policies that would drive the largest proportion of the inflows of FDI in the direction of manufacturing sub sector in the country. Similarly, all hands must be on deck by all the relevant stakeholders to ensure that manufactured products in Nigeria possesses value added quality to facilitate their competitiveness in the global market.

\section{References}

Aderemi, T.A., Ogunleye, A.G., Lucas, B.O., and Okoh, J.I., 2020. Globalization and Economic Growth: Evidence from European Countries. European Financial and Accounting Journal, 15(1), pp. 67-82, http://efaj.vse.cz/doi/10.18267/j.efaj.234.pdf.

Adofu, I., \& Okwanya, I., 2017. Linkages between Trade Openness, Productivity and Industrialization in Nigeria: A Co-integration Test. Research in World Economy, 8(2),URL: https://doi.org/10.5430/rwe.v8n2p78, http://rwe.sciedupress.com.

Agbarha, E.K., \& Peter, S.A., 2017. Globalization and Economic Growth in Nigeria: A Cointegration Approach. Journal of International Business and Economics, American Research Institute for Policy Development, 5(1), pp. 105-113. DOI: 10.15640/jibe.v5n1a9. 
Akindele, D.B., Jogunola, A. and Aderemi, T.A., 2019. Globalisation and Real Estate Development in Nigeria: An Empirical Perspective. Saudi Journal of Economics and Finance, 3(7), pp. 294-297, DOI:10.21276/sjef.2019.3.7.3.

Akor, A.A, Yongu, V.M. \& Akorga M.T., 2012. Effects of globalization on the Nigeria economy. Journal of Management and Corporate Governance, 4, pp. 1-6.

Awake, A., 2002. Globalization: Curse or cure? New York: Watch Tower and Tract Society. Ayanwale A. B., 2007. FDI and economic growth: Evidence from Nigeria. Nairobi: African Economic Research Consortium, Paper 165.

Baldwin, R.E. and G.G. Cain, 2000. Shifts in U.S. Relative Wages: The Role of Trade, Technology, and Factor Endowments`. The Review of Economics and Statistics, 82(4), pp. 580-95, http://www.mitpressjournals.org/doi/pdf/10.1162/003465300559064.

Binuyo B.O., Oluwadare, A.A., Ayodele, O. Olanrewaju, G.O. and Obiakor, R., 2017. Impact of Globalization on the Industrial Growth in Nigeria (1981 - 2014): Implication to Psychologist and Economist. European Journal of Business, Economics and Accountancy, 5(5), pp. 52-60.

Dappa, T., and Thom-otuya, B., 2010. The Effects of Globalization on Developing Economies: The Nigerian Experience. Sophia: An African Journal of Philosophy, 12(2), pp.56-63

Dembele, D.M., 1998. Africa in the twenty-first century.

Dreher A, Gaston N, Martens P., 2008. Measuring globalization: Gauging its consequences. Springer Verlag.

Dollar, D. and Kraay, A., 2001. Growth is good for the poor. Policy Research Working Paper No. 2587, World Bank Group.

Ebong, F, Udoh E. and Obafemi, F., 2014. Globalization and the Industrial Development of Nigeria: $\quad$ Evidence from Time Series Analysis. International Review of Social Sciences and Humanities, 6(2), pp. 12-24.

Feridun, M., Olusi, J.O., and Folorunso, B.A., 2006. Analyzing the impact of globalization on economic development in developing economies: an application of Error Correction Modelling (ECM) to Nigeria. Applied Econometrics and International Development, I (6-3), pp. 174-182.

Burtless, G., Lawrence, R.Z., Litan, R.E., Shapiro, R.J., 1998. Globaphobia: Confronting fear about open trade: Washington, D.C: Brookings Institute Press.

George-Anokwuru, C.C., 2018. Economic Globalization and Growth of the Nigerian Economy. IIARD International Journal of Economics and Business Management, 4(2), pp.51-60.

Imandojemu, K. Akinlosotu, N.T. and Aina, J.B., 2021. Globalization and Economic Growth in Nigeria. International Journal of Economics, Commerce and Management 10(1), pp. 185203.

Gondwen, G.E., 2007. Making globalization work in Africa. Finance and Development, 38(4), pp. 31-33. DOI: https://doi.org/10.5089/9781451951974.022

Kovářová, E., 2017. Economic Globalization Effects and Openness to Trade of the ECOWAS Member States. Studia Ekonomiczne, 10, pp. 8-17.

Letswa, A.M., Raji, S.A. and Edita, M.N., 2018. The Effects of Globalization on African Economic Development: The Nigerian Experience. International Journal of Arts and Humanities (IJAH) Ethiopia, 7 (2), pp. 98-103, DOI: http://dx.doi.org/10.4314/ijah.v7i2.12.

Kaya, Y., 2010. Globalization and Industrialization in 64 Developing Countries, 1980-2003. Social Forces, 88(3), pp. 2-30. DOI: 10.1353/sof.0.0300.

Odo, C.O., Agbo, I., and Agbaji, B., 2020. Globalization and Developing Economy: Evidence from Nigeria. Journal of Financial Risk Management, 9, pp, 518-530, doi: 10.4236/jfrm.2020.94028. DOI: 10.4236/jfrm.2020.94028. 
Okpokpo, G.U., Ifelunini, I.A., \& Osuyali, F., 2014. Is globalisation a potent driver of economic growth? Investigating the Nigerian non-oil exports. Asian Economic and Financial Review, 4(6), pp. 781-792.

Onwuka, E.C., and Eguavoen, A., 2018. Globalization and Economic Development: The Nigerian Experience. Journal of Social Sciences, https://doi.org/10.1080/09718923.2007.11978398.

Olowookere, J.K., Hassan, A.O., Adewole, A.O. and Aderemi, T.A., 2021. Small and Medium Scale Enterprises (SMEs) Financing and Sustainable Economic Growth in Nigeria. The Journal of Accounting and Management, 11(1), pp. 220-228.

Parisa, S. and Hashem, J.S., 2014. Globalization and Economic Growth: Empirical Evidence on the Role of Complementarities. PLoS ONE 9(4): e87824.doi:10.1371/journal.pone.0087824

Rodrik, D., 1999. The new global economic and the developing countries: Making openness work. Baltimore: John Hopkin University Press.

Saibu, M. and Akinbobola, T., 2014. Globalization, Foreign Direct Investment and Economic Growth in Sub Saharan Africa. Journal of Economics and International Finance, 6(3), pp. 62-68, DOI: 10.5897/JEIF2013.0531.

Salimono, A., 1999. Globalization and challenges. A Paper Presented at the International Summit on Globalization as problem of development in Havana Cuba. Jan.18-22.

Toyin, A., 2017. Globalization and Industrial Development: The Nigerian Perspective. East Asian Journal of Business Economics, 5(1), pp. 1-9, DOI: 10.20498/eajbe.2017.5.1.1.

Uwadiegwu, O., 2015. Globalization and Industrial Development in Nigeria. IOSR Journal of Humanities and Social Science (IOSR-JHSS), 20(1), pp. 62-122.

Vogel, D., 1999. Barrier or Benefits? Regulation transatlantic trade. Washington D.C: Brookings Institute Press.

World Bank, 2016. Data, http://data.worldbank.org/indicator/NE.TRD.GNFS.ZS (accessed: 5.08.2016).

\section{Bio-note}

Dr. Omoyele, $O$. S. is a researcher and senior lecturer in the Department of Business Administration and Marketing, Redeemer's University, Ede, Osun State, Nigeria. He is an $\mathrm{Ag}$, Director, Redeemer`s University Centre for Entrepreneurship Development. He is a Principal Consultant/Business Advisor to Eduplus Consult, Lagos. He attended and presented papers at Conferences. He has publications to his credit.

Dr. Lucas B. Ojo is a chief lecturer at School of Technical Education, Yaba College of Technology, Lagos, and Coordinator of Bachelor Degree programmes in Affiliation with University of Nigeria, UNN, Nsukka, Nigeria.

Dr. Olanipekun, W. D. is an X-Culture Certified Global Business Educator, a Faculty Member in the College of Management and Information Technology and Director of Collaboration, Research and Consultancy Centre in American International University, West Africa, The Gambia.

Timothy Ayomitunde ADEREMI is a lecturer II and researcher at Bells University of Technology, Ota, Nigeria, PhD Candidate, Olabisi Onabanjo University, Ago-Iwoye, Nigeria and an associate member, Centre for Economic Policy and Development Research (CEPDeR), Covenant University, Ota, Nigeria. He has an extensive wealth of experience in Applied Econometrics, Methodology and International Economics. He authored over fifty (50) research articles in International Journals. He is a speaker at international conferences, and serves as a reviewer for several International Journals such as Emerald Journals, European Journal of Economics, Politics and Law, Acta Danubius Universitas etc. 